\title{
PREVALENSI PROTOZOA USUS PADA KUKANG SUMATERA (Nycticebus coucang) MELALUI PENGGUNAAN BERBAGAI MACAM MEDIA PENGAWET DAN KONSENTRASI BERBEDA DI PUSAT REHABILITASI YIARI CIAPUS, BOGOR
}

\section{THE PREVALENCE OF INTESTINAL PROTOZOAN IN SUMATRAN SLOW LORIS (Nycticebus coucang) THROUGH THE USE OF VARIOUS KINDS OF MEDIA AND DIFFERENT CONCENTRATIONS OF PRESERVATIVES IN THE REHABILITATION CENTER YIARI CIAPUS, BOGOR}

\author{
Nora Rukmana $^{1 \star}$, Emantis Rosa ${ }^{1}$, Wendi Prameswari ${ }^{2}$ \\ 1Jurusan Biologi Fakultas MIPA Universitas Lampung \\ ${ }^{2}$ International Animal Rescue Indonesia \\ *norarukmana@gmail.com
}

\begin{abstract}
ABSTRAK
Penelitian ini bertujuan untuk mengetahui jenis protozoa, jumlah ookista dan prevalensi kukang sumatera (Nycticebus coucang) yang terinfeksi protozoa usus dengan menggunakan berbagai macam media pengawet dan konsentrasi berbeda. Penelitian ini dilakukan pada lima ekor kukang sumatera. Pengambilan sampel dilakukan pada malam hari dan diawetkan pada berbagai macam media kontrol (tanpa larutan), alkohol $70 \%$, alkohol $80 \%$, formalin $5 \%$, dan formalin $10 \%$. Penelitian ini menggunakan dua metode yaitu metode pemeriksaan natif dan metode apung. Pemeriksaan sampel dilakukan di Laboratorium Diagnostik, YIARI dan Laboratorium Biologi, Fakultas Matematika dan IImu Pengetahuan Alam, Universitas Lampung. Hasil pemeriksaan dengan metode natif diperoleh dua kelompok protozoa yaitu protozoa parasitik dan protozoa non parasitik. Protozoa parasitik diperoleh tiga famili yaitu Eimeriidae, Endamobidae, dan Balantiidae dengan empat jenis yaitu Isospora sp., Cryptosporidium parvum, Entamoeba coli, dan Balantidium coli. Sedangkan hasil identifikasi Protozoa non parasitik hanya ditemukan famili Oxytrichidae dengan satu jenis yaitu Oxytricha granulifera. Hasil perhitungan dengan metode apung diperoleh ookista Eimeria sp. dengan jumlah $200 \mathrm{sel} / \mathrm{gram}$. Prevalensi protozoa usus melalui penggunaan berbagai macam media dan konsentrasi berbeda pada kukang sumatera yaitu $2 \%$ pada kontrol, $9,2 \%$ pada alkohol $70 \%, 13 \%$ pada alkohol $80 \%, 5,8 \%$ pada formalin $5 \%$, dan $5,4 \%$ pada formalin $10 \%$. Media alkohol $80 \%$ menjadi rekomendasi paling bagus sebagai media pengawet protozoa usus dibandingkan dengan alkohol $70 \%$, formalin $5 \%$, dan formalin $10 \%$.
\end{abstract}

Kata kunci: Nycticebus coucang, protozoa usus,protozoa parasitik, protozoa non parasitik

\section{ABSTRACT}

The purpose of this study to determine the types of protozoa, total oocysts, and prevalence of sumatran slow loris (Nycticebus coucang) were infected intestinal protozoa by using a variety of media and different concentrations of preservative. The study was conducted at five sumatran slow loris. Sampling was conducted at night and preserved on a variety of media (control/ no solution), alcohol 70\%, alcohol 80\%, formalin 5\%, and formalin 10\%. This study uses two methods of collation method native and floating method. Examination of samples conducted in the laboratory diagnostics, YIARI and biological laboratory, Faculty of Mathematics and Natural Sciences, Lampung University. The results of the examination by the method native obtained two groups of protozoa an parasitic protozoa and non parasitic protozoa. A parasitic protozoan retrieved three of the family Eimeriidae, Endamobidae, and Balantiidae with four types Isospora sp., Cryptosporidium parvum, Entamoeba coli, dan Balantidium coli. While the results of the identification of non parasitic protozoa found only Oxytrichidae family is Oxytricha granulifera. The result of calculations with floating method of Eimeria sp. oocysts $200 \mathrm{cells} / \mathrm{gram}$. The prevalence of intestinal protozoa by using a variety of media and different concentrations of preservative on sumatran slow loris include $2 \%$ in control, 9,2\% in alcohol 70\%, 13\% in alcohol 80\%, 5,8\% in formalin 5\%, and 5,4 in formalin $10 \%$. The media alcohol $80 \%$ being the most flattering recommendation as intestinal protozoa preservative media compared with alcohol $70 \%$, formalin $5 \%$, and formalin $10 \%$.

Keyword: Nycticebus coucang, intestinal protozoa, parasitic protozoa, non parasitic protozoa 


\section{PENDAHULUAN}

Indonesia merupakan negara yang kaya akan flora dan fauna salah satunya jenis primata eksotis yang melimpah. Jenis primata di Indonesia yang mencapai 36 jenis dan memiliki nilai estetika yang tinggi dan sering diperdagangkan. Salah satu dari primata yang memiliki nilai eksotis yaitu kukang sumatera.

Kukang sumatera dikategorikan sebagai spesies yang langka dikarenakan banyaknya ancaman serius terhadap kelestariannya. Hal itu dikarenakan tingginya tingkat perburuan dan perdagangan ilegal, rendahnya tingkat kelahiran yang hanya menghasilkan satu anak dalam satu tahun, serta infeksi penyakit. Salah satu penyakit yang dapat menginfeksi kukang yaitu protozoa parasitik (protozoa usus). Infeksi protozoa dapat disebabkan oleh lingkungan habitat atau sumber pakan yang tidak higienis. Keberadaan protozoa parasitik (protozoa usus) dapat berubah sesuai dengan kondisi dan suhu lingkungan (Herdaus,2015).

Protozoa usus mempunyai siklus hidup yang berbeda dalam setiap spesies dan mampu berkembang dalam kondisi usus yang sesuai dan jumlah asupan makanan yang cukup. Protozoa usus memiliki dampak negatif dalam kehidupan kukang yang menyebabkan tidak nafsu makan, berat badan berkurang, diare bahkan terjadi kematian (Assafa et.al,. 2004).

Kukang sumatera termasuk dalam status Appendix I berdasarkan Convention on International Trade in Endangered Spesies of
Wild Flora and Fauna (CITES) (CITES,2007). Berdasarkan kategori International Union for Conservation of Nature and Natural Resources (IUCN) (2013) bahwa kukang sumatera berstatus vulnerable (rentan) (IUCN,2013).

Protozoa usus terdiri atas amebae, flagellata, dan cilliata. Amebae yang berada di saluran pencernaan adalah Entamoeba histolytica, Entamoeba coli, Entamoeba hartmani, Endolimax nana, lodamoeba butschlii, Dientamoeba frgailis, dan Blastocystis hominis. Protozoa usus yang termasuk ke dalam flagellata yaitu Giardia lamblia. Sedangkan protozoa usus yang termasuk cilliata adalah Balantidium coli (Yulfi,2006).

Penelitian ini bertujuan untuk mengetahui jenis dan jumlah ookista, dan prevalensi protozoa usus yang menginfeksi kukang sumatera (N.coucang) dalam perbedaan media pengawet dan konsentrasi di kandang rehabilitasi YIARI Ciapus, Bogor.

\section{BAHAN DAN METODE}

\section{Waktu dan Tempat}

Penelitian ini dilaksanakan pada Januari sampai April 2016 yang dilakukan dalam dua tahapan yaitu pengambilan sampel feses dilakukan di kandang Rehabilitasi Satwa Primata YIARI di Ciapus, Bogor dan pemeriksaan sampel di Laboratorium Diagnostik Parasitologi YIARI dan Laboratorium Biologi Fakultas Matematika dan IImu Pengetahuan Alam, Universitas Lampung. 


\section{Alat dan Ba han}

\section{Alat dan Bahan di Lapangan}

Alat yang digunakan yaitu es balok, jelly pack beku, cooler box, botol plastik $30 \mathrm{ml}$, sendok, sarung tangan, kertas label, alat tulis dan kamera digital sedangkan bahan yang digunakan meliputi feses kukang sumatera, alkohol $70 \%$, alkohol $80 \%$, formalin $5 \%$ dan formalin $10 \%$.

\section{Alat dan Bahan di Laboratorium}

Alat yangdigunakan pada saat pemeriksaan sampel di laboratorium meliputi gelas ukur, saringan, spatula, gelas objek, gelas beaker, gelas penutup, mikroskop cahaya, mikrometer okuler, mikrometer objektif, lemari es, timbangan digital, pipet tetes, alat tulis, sentrifugasi, dan kamera digital sedangkan bahan yang digunakan meliputi feses kukang sumatera, larutan $\mathrm{NaCl}$ jenuh, dan aquades. Larutan $\mathrm{NaCl}$ jenuh dibuat dengan cara melarutkan $\mathrm{NaCl}$ dengan 1 liter aquades sampai kristal $\mathrm{NaCl}$ tidak dapat larut lagi di dalam aquades.

\section{Cara Kerja}

\section{Metode Pengambilan Sampel}

Pengambilan sampel kukang sumatera dilakukan selama 20 hari terhadap lima ekor kukang sumatera bernama Atep, Bebeb, Harendong, Kamilo, dan Loco.

Pengambilan sampel dilakukan pada malam hari sebanyak 3-5 gram dari masing-masing individu kukang sumatera dengan cara ditunggu sampai kukang melakukan defekasi. Setelah kukang melakukan defekasi diambil fesesnya dan dimasukkan dalam botol plastik $30 \mathrm{ml}$ yang sudah berisi alkohol $70 \%$, alkohol $80 \%$, formalin $5 \%$, formalin 10\% dan (kontrol/tanpa larutan media). Botol plastik yang sudah dimasukkan sampel feses diberi label dan disimpan dalam cooler box yang berisi jelly pack beku. Kemudian, sampel disimpan dalam kulkas dengan suhu $3^{\circ} \mathrm{C}$ untuk menghindari perkembangan telur. Pemberian label pada sampel feses meliputi nama kukang, kondisi feses, lokasi pengambilan, waktu dan tanggal pengambilan, cuaca, dan larutan media yang digunakan (Shaikenov et al. 2004).

\section{Metode Pemeriksaan Sampel}

Pemeriksaan sampel feses kukang sumatera dilakukan dengan menggunakan dua metode yaitu metode pemeriksaan natif dan metode apung. Metode pemeriksaan natif meliputi feses kukang sumatera yang sudah disiapkan, ditimbang sebanyak 3 gram dan dimasukkan ke dalam gelas beaker. Kemudian ditambahkan $57 \mathrm{ml}$ aquades dihomogenkan dan disaring dengan kain kasa dan ditempatkan pada gelas beaker. Hasil saringan diambil dengan pipet tetes sebanyak 3-5 tetes di gelas objek dan diperiksa di bawah mikroskop (Rinaldi et al. 2014).

Pemeriksaan sampel dengan metode apung meliputi feses segar kukang sumatera diambil sebanyak 2 gram dilarutkan ke dalam $3 \mathrm{ml}$ aquades dan dihomogenkan di dalam gelas beaker. Setelah itu disaring menggunakan kain kasa berukuran 10×10 $\mathrm{cm}$. Kemudian ditambahkan $10 \mathrm{ml}$ larutan $\mathrm{NaCl}$ jenuh dan dihomogenkan (Taylor et.al., 2007). Setelah homogen larutan disaring kembali dengan kain kasa dan dituang ke dalam tabung sentrifugasi sampai 3/4. 
Tabung disentrifugasi selama 5 menit dengan kecepatan 1500 rpm. Setelah disentrifugasi, larutan yang terdapat pada permukaan diambil dengan spatula dan diteteskan di atas object glass. Kemudian ditutup dengan cover glass dan diperiksa di bawah mikroskop dengan perbesaran 100x (okuler $\mathrm{x}$ objektif) (Natadisastra dan Agoes, 2009).

\section{Analisis Data}

Analisis data dilakukan secara deskriptif. Penentuan angka prevalensi didapat menggunakan rumus menurut Gaspersz (1991):

Prevalensi $=\frac{N}{S} \times 100 \%$

dimana:

$\mathrm{N}$ : jumlah kukang sumatera positif terinfeksi protozoa

$S$ : jumlah total kukang sumatera yang diperiksa

Untuk mengetahui jumlah ookista digunakan rumus menurut Colville (1991) dan Nolan (2006):

Jumlah ookista $=$ Ookista yang ditemukan pada kamar hitung $\times 100$ (sel/gram)

\section{HASIL DAN PEMBAHASAN}

Hasil Identifikasi Protozoa Usus pada Kukang Sumatera ( $N$. coucang) dengan Metode Natif

Hasil identifikasi protozoa usus yang menginfeksi kukang sumatera menggunakan metode natif ditemukan tiga famili dan empat jenis protozoa parasitik (Gambar 1) serta satu famili dan satu jenis protozoa nonparasitik (Gambar 2).

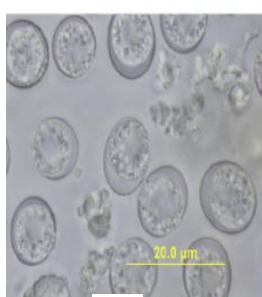

A

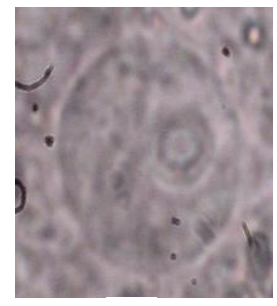

C

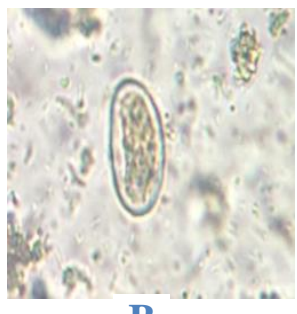

B

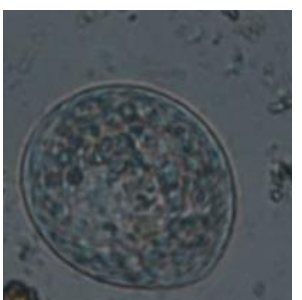

D
Gambar 1. Hasil pengamatan protozoa parasitik pada kukang sumatera (Ket: A).Isospora sp. (400x), B).Cryptosporidium parvum (400x), C). Entamoeba coli (400x), D).Balantidium coli $(400 x))$

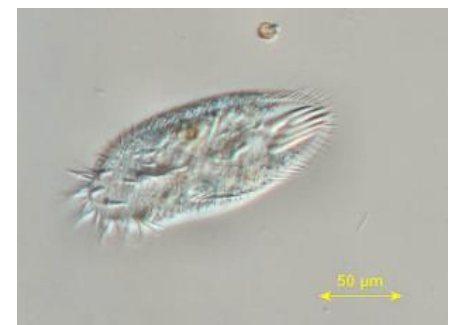

Gambar 2. Hasil pemeriksaan protozoa non parasitik (Oxytricha granulifera) pada kukang sumatera

\section{Perhitungan Ookista pada Sampel Feses Kukang Sumatera ( $N$. coucang) dengan Metode Apung}

Hasil pemeriksaan sampel dengan menggunakan metode apung dari total sampel feses diperoleh hasil bahwa sampel feses kukang sumatera positif terinfeksi ookista Eimeria sp. yang ditunjukkan pada Tabel 2. 
Tabel 2. Hasil perhitungan ookista pada sampel feses kukang sumatera ( $N$. coucang) dengan metode apung

\begin{tabular}{|c|c|c|c|c|c|c|c|c|c|c|c|c|c|c|c|c|c|c|c|c|c|c|}
\hline \multirow{3}{*}{ No. } & \multirow{3}{*}{ Protozoa } & \multirow{3}{*}{$\begin{array}{c}\text { Larutan } \\
\text { Media }\end{array}$} & \multicolumn{20}{|c|}{ Sampel Feses Kukang Sunatera } \\
\hline & & & \multicolumn{4}{|c|}{ Kukang Atep } & \multicolumn{4}{|c|}{ Kukang Bebeb } & \multicolumn{4}{|c|}{ Kukang Harendong } & \multicolumn{4}{|c|}{ Kukang Kamilo } & \multicolumn{4}{|c|}{ Kukang Loco } \\
\hline & & & P.1 & U.1 & U.2 & $\overline{\mathrm{U} .3}$ & P.1 & U.1 & U.2 & $\overline{\mathrm{U}} .3$ & P.1 & $\mathrm{U} .1$ & $\mathrm{U} .2$ & $\mathrm{U} .3$ & P.1 & U.1 & $\mathrm{U} .2$ & $\mathrm{U} .3$ & P.1 & $\overline{\mathrm{U}} .1$ & $\mathrm{U} .2$ & $\overline{\mathrm{U}} .3$ \\
\hline \multirow{5}{*}{1.} & \multirow{5}{*}{$\begin{array}{l}\text { Jenis Oolista } \\
\text { yang ditemukan: } \\
\text { a. Eimeria sp. }\end{array}$} & Kontrol & - & - & - & - & - & - & - & - & - & - & - & - & - & - & - & - & - & - & - & - \\
\hline & & $\begin{array}{l}\text { Allkohol } \\
70 \%\end{array}$ & - & - & - & - & - & - & - & - & - & - & - & 1 & - & - & - & - & - & - & - & - \\
\hline & & $\begin{array}{l}\text { Allkohol } \\
80 \%\end{array}$ & - & - & - & - & - & - & - & - & - & - & - & 1 & - & - & - & - & - & - & - & - \\
\hline & & $\begin{array}{c}\text { Formalin } \\
\mathbf{5} \%\end{array}$ & - & - & - & - & - & - & - & - & - & - & - & - & - & - & - & - & - & - & - & - \\
\hline & & $\begin{array}{c}\text { Formalin } \\
10 \%\end{array}$ & - & - & - & - & - & - & - & - & - & - & - & - & - & - & - & - & - & - & - & - \\
\hline & Junlah Oolista & & - & - & - & - & - & - & - & - & - & - & - & $\begin{array}{c}200 \\
\text { sell } \\
\text { gram }\end{array}$ & - & - & - & - & - & - & - & - \\
\hline
\end{tabular}

Keterangan: (P.1): Pengambilan ke-1 ; (U.1): Ulangan 1; (U.2): Ulangan 2; (U.3): Ulangan 3; (-): Tidak terinfeksi protozoa

Hasil identifikasi ditemukan dua ookista Eimeria, sp. pada media alkohol $70 \%$ dan alkohol $80 \%$. Hal ini kemungkinan dikarenakan didukung oleh suhu daerah ciapus bogor pada saat pengambilan sampel feses kukang Harendong antara $24^{\circ}-25^{\circ} \mathrm{C}$ sehingga menyebabkan Eimeria sp. dapat menginfeksi lebih cepat dan mudah untuk mempertahankan hidupnya. Selain itu juga adanya feses tikus liar di dalam kandang kukang harendong. Hal ini sesuai dengan Safar (2010) bahwa infeksi famili Eimeriidae terjadi karena adanya kontak langsung dengan kotoran tikus liar. Infeksi famili ini lebih sering terjadi di negara yang sedang berkembang dibanding dengan negara maju dan famili Eimeriidae dapat hidup lama di air dan tidak dapat bertahan hidup pada pengeringan. Ookista Eimeria sp. yang menginfeksi kukang sumatera ditunjukkan pada Gambar 3.

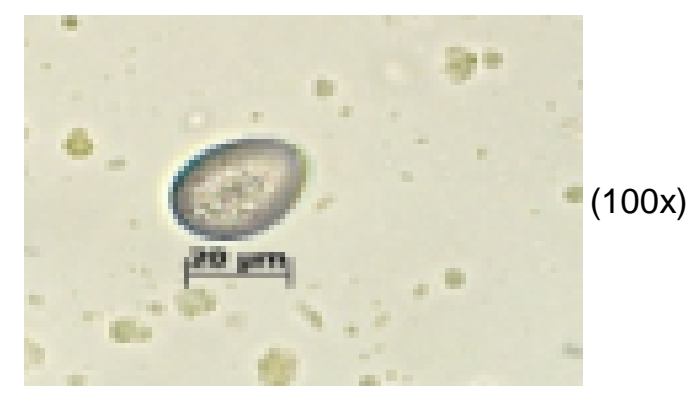

Gambar 3. Ookista eimeria sp. yang ditemukan pada kukang sumatera ( $N$. coucang) dalam larutan alkohol $70 \%$ dan alkohol $80 \%$

\section{Prevalensi Protozoa Usus melalui Media}

Pengawet dan Konsentrasi Berbeda pada Kukang Sumatera ( $N$. coucang)

Prevalensi protozoa usus melalui penggunaan media pengawet dan konsentrasi berbeda ditemukan prevalensi berdasarkan media alkohol $80 \%$ sebesar $13 \%$ dibandingkan dengan tanpa larutan media, media alkohol $70 \%$, formalin $5 \%$, dan formalin 10\% (Tabel 3). 
Tabel 3. Prevalensi protozoa usus pada kukang sumatera (N. coucang) berdasarkan media pengawet dan konsentrasi berbeda

\begin{tabular}{|c|c|c|c|c|c|c|}
\hline \multirow[t]{2}{*}{ No } & \multirow[t]{2}{*}{ Protozoa } & \multicolumn{5}{|c|}{ Prevalensi (\%) } \\
\hline & & Kontrol & $\begin{array}{c}\text { Alkohol } \\
70 \%\end{array}$ & Alkohol 80\% & Formalin 5\% & $\begin{array}{c}\text { Formalin } \\
10 \%\end{array}$ \\
\hline \multirow[t]{3}{*}{1} & Famili Eimeriidae & & & & & \\
\hline & a. Isospora sp. & 4 & 5 & 5 & 4 & 6 \\
\hline & b. Cryptosporidium parvum & 3 & 9 & 9 & 6 & 6 \\
\hline \multirow[t]{2}{*}{2} & Famili Endamoebidae & & & & & \\
\hline & Entamoeba coli & 2 & 28 & 44 & 17 & 15 \\
\hline \multirow[t]{2}{*}{3} & Famili Balantiidae & & & & & \\
\hline & Balantidium coli & 1 & 4 & 6 & 2 & 0 \\
\hline \multirow[t]{3}{*}{4} & Famili Oxytrichidae & & & & & \\
\hline & Oxytricha granulifera & 0 & 0 & 1 & 0 & 0 \\
\hline & Rata-rata & 2 & $\overline{9,2}$ & 13 & $\overline{5,8}$ & $\overline{5,4}$ \\
\hline
\end{tabular}

Prevalensi protozoa usus lebih banyak ditemukan pada media alhohol dibandingkan dengan media formalin. Hal ini kemungkinan dikarenakan pada media alkohol tidak terlalu merusak dinding sel dari protozoa dan tidak menyebabkan lisis yang berlebihan. Menurut Shields dan Carlson (1996) menyatakan bahwa alkohol lebih cepat menembus jaringan dan dapat digunakan dalam jangka waktu yang lama dengan melakukan pergantian tanpa merusak jaringan dan mengakibatkan lisis yang berlebihan. Sedangkan formalin mengawetkan dalam jangka waktu lama tanpa pergantian. Akan tetapi, media tersebut menyebabkan hewanhewan kecil menjadi lisis atau hilang.

\section{KESIMPULAN}

Berdasarkan hasil penelitian yang telah dilakukan dapat disimpulkan bahwa:

1. Hasil identifikasi protozoa parasitik pada feses kukang sumatera menggunakan metode natif diperoleh tiga famili yaitu Eimeriidae, Endamoebidae, dan Balantiidae dengan empat spesies protozoa yaitu Isospora sp., Cryptosporidium parvum, Entamoeba coli, dan Balantidium coli. Sedangkan hasil identifikasi protozoa non parasitik hanya diperoleh satu famili yaitu Oxytrichidae dengan satu spesies Oxytrichia granulifera.

2. Hasil jumlah perhitungan ookista dengan metode apung ditemukan ookista Eimeria sp. dengan jumlah $200 \mathrm{sel} / \mathrm{gram}$.

3. Prevalensi protozoa usus yang menginfeksi kukang sumatera pada feses yang tidak diberi larutan media sebesar $2 \%$, feses yang diberi alkohol70\% sebesar 9,2\%, feses yang diberi alkohol $80 \%$ sebesar $13 \%$, feses yang diberi formalin $5 \%$ sebesar $5,8 \%$, dan feses yang diberikan formalin $10 \%$ sebesar $5,4 \%$.

\section{DAFTAR PUSTAKA}

Al-Hindi, A. I. 2009. A Practical Guide to Diagnostic Medical Parasitology. Islamic University of Gaza Press. Islamic University of Gaza.

Assafa, D., E. Kibru, S. Nagesh, S. Gebreselassie, F. Deribe, dan J. Ali. 2004. Medical Parasitology. Ethiopia Public Health Training Initiative. The Carter Center, The Ethiopia Ministry of Health, and The Ethiopia Ministry of Education. Pp 150. 
[CITES] Convention on International Trade in Endangered Species of Wild Flora and Fauna. 2007. Appendices [Internet]. Terdapat pada: http://cites.org/eng/app/appendices.ph p. Diakses pada: 11 Nov 2015.

Colville, J. 1991. Diagnostic Parasitologu for Veterinary Technicians. American Veterinery Publications Inc. 5782. Thornwood, Drive Goleta, California 93177. Pp 19-26.

Herdaus, D. D. 2015. Identifikasi Dan Prevalensi Protozoa Parasitik Pada Sampel Feses Gajah Sumatera (Elephas Maximus Sumatranus) Di Pusat Konservasi Gajah,Taman Nasional Way Kambas [Skripsi]. Jurusan Biologi Fakultas MIPA Universitas Lampung. Lampung.

[IUCN]. 2013. Nycticebus coucang : The IUCN red list of threatened species. Geneva $(\mathrm{CH})$ : IUCN. Version 2014.2 [Internet]. $\quad$ Terdapat pada:http://www.iucnredlist.org/details/ 39759/0. Diakses pada 11 Nov 2015.

Natadisastra, D., R. Agoes. 2009. Parasitologi kedokteran: ditinjau dari organ tubuh yang diserang. Penerbit buku kedokteran EGC. Jakarta.

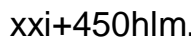

Nolan, T. 2006. McMaster Egg Couting Technique [Internet]. Terdapatpada:http://cal.vet.upenn.edu/ projects/parasit06/website/mcmaster.ht m. Diakses pada 12 Nov 2015.

Rinaldi L, Levecke B, Boscoa A, lanniello D, Pepe P, Charlier J, Cringolia G,Vercruyss J. 2014. Comparison of individual and pooled faecal samples in

sheep for the assessment of gastrointestinal strongyle infection inteAity and anthelmintic drug efficacy using McMaster and Mini-FLOTAC. Veterinary Parasitology 6(11): 1-8.
Shaikenov BS, Rysmukhambetova AT, Massenov B, Deplazes P, Mathis A, dan

Torgerson PR. 2004. Shot Report : The use of a polymerase chain reaction to detect Echinococcus granulosus (G1 Strain) egg in soil sample. American Journal of Tropical Medicine Hygiene. 71(4): 441-443.

Sucitrayani, P.T.E., I. B. M. Oka., M. Dwinata. 2014. Prevalensi Infeksi Protozoa Saluran Pencernaan Pada Kucing Lokal (Felis catus) di Denpasar. Buletin Veteriner Udayana. 6(2):2085-2495.

Taylor, M. A.,R.L. Coop., R.L.Wall. 2007. Veterinary parasitology. 3rd ed. Blackwell publishing Ltd. Oxford : xxvi $+874 \mathrm{hlm}$.

Yulfi, H. 2006. Protozoa Intestinalis. USU Repository. Medan Sumatera Utara

Zaman, V. 1997. Atlas Parasitologi Kedokteran edisi II. Hipokrates. Jakarta 
---This page left blank--- 